More Art in the public eye 


\author{
Published by \\ More Art Press \\ The Neighborhood Preservation Center \\ 232 East 11 Street \\ New York, NY 10003 \\ 646.416.6940 \\ www.moreart.org \\ Designed by \\ CENTO50 (Nicholas Sabena, Giovanni Sambo, Enrico Tarò)
}

Editors

Micaela Martegani

Jeff Kasper

Emma Drew

Copy Editor

Madeleine Compagnon

Printed by

Tipostampa, Turin, IT

\title{
Cover photo
}

Residents of New York, Andres Serrano (2014)

\section{Copyright 2019 More Art}

\section{Distributed by Duke University Press}

All rights reserved. No part of this publication may be reproduced, stored in retrieval systems, or transmitted in any form or by any means, electronic, mechanical, photocopying, recording, or otherwise, without the prior permission of the copyright holder.

The copyright of the works of art reproduced in this catalogue are retained by the artists.

Every effort has been made to trace copyright owners of third party material. Anyone claiming copyright is asked to contact More Art immediately.

Names: Martegani Micaela, editor. | Kasper Jeff, editor. | Drew Emma, editor.

Title: More art in the public eye / Micaela Martegani, Jeff Kasper, Emma Drew, editors. Description: Includes bibliographical references and index.

New York, NY: More Art Press, 2019.

Identifiers: LCCN 2019905431 | ISBN 978-1-7330993-0-1 (pbk.) |

978-1-7330993-2-5 (epub)

Subjects: LCSH Public art--United States. | Urban beautification--United States. | Art and society. I Public art--Political aspects--United States. I Interactive art--Political aspects--United States. I Arts, American--New York (State)--New York--20th century. | Arts, American--New York (State)--New York--21st century. | Public art--New York (State)--New York.

BISAC AwRT / Public Art | ART / Art \& Politics

Classification: LCC N8835 .M67 2019 | DDC 701/.030973--dc23. 
Dedicated to our mentor,

Tim Rollins (1955-2017) 
This page intentionally left blank 